\title{
Prawo do tłumaczenia pokrzywdzonego w polskim procesie karnym - wybrane zagadnienia
}

\begin{abstract}
The analysis of the provisions of the Code of Criminal Procedure shows a clear asymmetry in the rights of the accused and the victim as regards the right to interpreting. Despite the implementation of subsequent amendments, the legislators consistently ignored the rights of the victim with regard to the right to interpreting; when they actually dealt with that issue, it was done in a fragmented and selective manner.

Moreover, the exegesis of the provisions on the right to interpreting leads to the conclusion that the analyzed right is not fully regulated by the provisions of the Code of Criminal Procedure, and some extremely important normative parts of it must be decoded from the Law on the System of Common Courts. Both these spheres interpenetrate each other, which is undeniably undesirable from the point of view of the standard of legal certainty and transparency.

This study aims at identifying legislative shortcomings, as well as at proposing de lege ferenda solutions in relation to the analyzed right of the victim to interpreting.
\end{abstract}

Keywords: right to interpreting, victim, asymmetry of rights

\section{Uwagi wprowadzające}

Prawo do tłumaczenia, a zatem prawo do korzystania z pomocy tłumacza, można analizować $\mathrm{z}$ wielu perspektyw. Jedną $\mathrm{z}$ nich jest bez wątpienia znaczenie tego prawa dla procesu karnego, a tym samym jego związek z zasadami procesowymi. Prawo to niewątpliwie jest istotne z punktu widzenia ustalenia stanu faktycznego sprawy, bowiem niejednokrotnie pozwala dotrzeć do źródła dowodowego, które nie włada językiem toczącego się postępowania. Wobec tego służy ono uzyskaniu niezbędnych 
informacji oraz pełnej wiedzy o zdarzeniu będącym przedmiotem osądu, a zatem jest istotne $\mathrm{z}$ punktu widzenia realizacji wymogów zasady prawdy materialnej.

Przede wszystkim jednak na prawo do tłumaczenia powinno się spoglądać z perspektywy gwarancyjnej. Instytucja prawa do tłumaczenia nierzadko bywa traktowana jako poboczne, mniej relewantne zagadnienie wobec innych elementów prawa do obrony. Tymczasem analizowane $\mathrm{w}$ niniejszej pracy uprawnienie winno być traktowane jako przyrodzone prawo człowieka, w tym sensie, że nikt nie chce pozostawać w nieświadomości, gdy ważą się jego losy, a prawo do tłumaczenia jest warunkiem sine qua non efektywnej realizacji większości gwarancji procesowych uczestników procesu karnego, a tym samym ich aktywnego udziału w tym procesie ${ }^{1}$.

W literaturze przedmiotu prawo do tłumaczenia poddawane jest analizie przede wszystkim z punktu widzenia oskarżonego oraz jego gwarancji procesowych, $w$ tym realizacji wymogów prawa do obrony ${ }^{2}$. Podobnie $\mathrm{w}$ orzecznictwie prawo do tłumaczenia łączone jest głównie z prawem do obrony ${ }^{3}$. Doktryna i judykatura wskazują również, że prawo do tłumaczenia stanowi warunek konieczny rzetelności postępowania karnego, skoro gwarantuje rzeczywisty udział oskarżonego w procesie karnym. Nie sposób bowiem uznać za rzetelny proces karny, w którym oskarżony nie rozumie jego przebiegu, a w konsekwencji nie może brać w nim efektywnie udziału ${ }^{4}$. Wypada jednak odnotować, że w ramach wzoru rzetelnego

${ }^{1}$ C. NowaK: Prawo do korzystania $z$ pomocy ttumacza $w$ europejskim i polskim prawie karnym. Prok. i Pr. 1998, nr 10, s. 90. Zob. również W.A. Schabas: The European Convention on Human Rights. A commentary. Oxford 2015, s. 206.

${ }^{2}$ Kodeks postępowania karnego. Komentarz. Red. A. SAKowicz. Warszawa 2018, s. 245; P. WilińsкI: Zasada prawa do obrony $w$ polskim procesie karnym. Warszawa 2006, s. 264, 326-332; P.K. SowIŃsKI: Uprawnienia składajace się na prawo oskarżonego do obrony. Uwagi na tle czynności oskarżonego oraz organów procesowych. Rzeszów 2012, s. 17, 26, 295-318; Kodeks postępowania karnego. Komentarz. Red. K. DuDKA. Warszawa 2018, s. 199-200; R.A. STEFAŃsKI: Udziat ttumacza $w$ postępowaniu karnym jako przejaw rzetelnego procesu karnego. W: Rzetelny proces karny. Księga Jubileuszowa Profesor Zofii Świdy. Red. J. SKorupKa. Warszawa 2009, s. 373; R.A. StefańsKi: Tłumacz $w$ procesie karnym. „Wojskowy Przegląd Prawniczy” 2006, nr 4, s. 99; Z. ŚwIDA: Prawo cudzoziemca do obrony. W: Przestępczość przygraniczna. Postępowanie karne przeciwko cudzoziemcom w Polsce. Red. A.J. Szwarc. Poznań 2000, s. 119.

${ }^{3}$ Por. przykładowo wyr. SN z dnia 3 kwietnia 2003 r., III KKN 143/01. LEX nr 78914.

${ }^{4}$ Kodeks postępowania karnego. Komentarz. Red. A. SaKowicz..., s. 245; K. Marszat: Proces karny. Zagadnienia ogólne. Katowice 2009, s. 65; R. Ponikowski, W. Posnow, J. SKorupKa, Z. Świda. W: Postępowanie karne. Część ogólna. Red. J. SkorupKa. Warszawa 2008; M. Pєachta: Postępowanie karne przeciwko cudzoziemcowi w świetle badań empirycznych. SP 1990, nr 2, s. 81; wyr. SN z dnia 22 marca 2007 r., V KK 190/06. Prok. i Pr. 2007, nr 10, poz. 11 . 
procesu karnego punktem odniesienia jest nie tylko oskarżony, ale także, $\mathrm{w}$ równej mierze, pokrzywdzony ${ }^{5}$, czego - jak zostanie wykazane w dalszej części pracy - ustawodawca zdaje się nie dostrzegać.

Analiza uregulowań Kodeksu postępowania karnego ${ }^{6}$ pozwala, po pierwsze, na sformułowanie tezy, zgodnie z którą występuje wyraźna asymetria uprawnień oskarżonego i pokrzywdzonego w zakresie prawa do tłumaczenia. Mimo bowiem wdrażania kolejnych nowelizacji ustawodawca konsekwentnie pomijał uprawnienia pokrzywdzonego w odniesieniu do prawa do tłumaczenia, a jeśli już zajmował się tym zagadnieniem, to czynił to w sposób fragmentaryczny i wybiórczy. Po drugie, egzegeza przepisów w przedmiocie prawa do tłumaczenia pokrzywdzonego prowadzi do wniosku, że analizowane prawo nie jest całościowo regulowane przez unormowania k.p.k., a niektóre - niezwykle istotne - jego fragmenty normatywne trzeba dekodować z ustawy Prawo o ustroju sądów powszechnych ${ }^{7}$. Obie te sfery wzajemnie się przenikają, co bezspornie jest sytuacją niepożądaną z punktu widzenia standardu pewności i transparentności prawa.

\section{Zarys nowelizacji Kodeksu postępowania karnego odnoszących się do prawa do tłumaczenia}

Jak już sygnalizowano, ustawodawca w ostatnich latach koncentrował swoje wysiłki przede wszystkim na prawie do tłumaczenia oskarżonego. Świadczą o tym ostatnie nowelizacje przepisów k.p.k. dotyczące uprawnień oskarżonego i podejrzanego.

Pierwotnie obowiązujący kodeks obejmował swoim zakresem dwie regulacje dotyczące prawa do tłumaczenia, a mianowicie art. $204 \S 1$ i § 2 k.p.k., nakazujący udział tłumacza w sytuacji, gdy zachodziła potrzeba przesłuchania głuchego lub niemego, a nie wystarczało porozumienie się z nim za pomocą pisma, przesłuchania osoby niewładającej językiem

${ }^{5}$ W orzecznictwie Europejskiego Trybunału Praw Człowieka zauważalna jest ostatnio tendencja do zmniejszania gwarancji rzetelności procesu wobec oskarżonych poprzez zwiększenie ochrony prawnej ofiar przestępstw. Podobną tendencję można zaobserwować również w odniesieniu do prawodawcy unijnego, por. przykładowo uregulowania Dyrektywy Parlamentu Europejskiego i Rady 2012/29/UE z dnia 25 października 2012 r. ustanawiającej normy minimalne w zakresie praw, wsparcia i ochrony ofiar przestępstw oraz zastępująca decyzję ramową Rady 2001/220/WSiSW, Dz.Urz.UE L 315/57 z dnia 14 listopada $2012 \mathrm{r}$.

${ }^{6}$ Ustawa z dnia 6 czerwca 1997 r. Kodeks postępowania karnego, t.j. Dz.U. 2020, poz. 30, 413, 568, 1086.

7 Ustawa z dnia 27 lipca 2001 r. - Prawo o ustroju sądów powszechnych, t.j. Dz.U. 2020, poz. 365, 288, 875, 1086. 
polskim, przełożenia na język polski pisma sporządzonego w języku obcym lub odwrotnie albo zapoznania oskarżonego z treścią przeprowadzanego dowodu, oraz art. 72 k.p.k., obligujący organy do przetłumaczenia wymienionych w tym przepisie aktów procesowych, jeżeli oskarżony nie władał językiem polskim, oraz do doręczenia ich oskarżonemu. Chodziło o postanowienia o przedstawieniu, uzupełnieniu lub zmianie zarzutów, akt oskarżenia oraz orzeczenia podlegające zaskarżeniu lub kończące postępowanie $^{8}$. Nadto k.p.k. pierwotnie gwarantował w art. $79 \S 1$ pkt 4 obronę obligatoryjną, jeżeli oskarżony nie władał językiem polskim, a także prawo do przetłumaczenia skrótu przemówień w toku głosów końcowych ${ }^{9}$.

Nowelizacją z dnia 10 stycznia 2003 r. ${ }^{10}$ dokonano zmiany art. 72 k.p.k. $\mathrm{w}$ ten sposób, że oprócz prawa do tłumaczenia pisemnego zagwarantowano oskarżonemu prawo do korzystania z bezpłatnej pomocy tłumacza, jeżeli nie włada w wystarczającym stopniu językiem polskim (art. 72 $\S 1$ k.p.k.) oraz zobowiązano organy procesowe do wezwania tłumacza do czynności z udziałem takiego oskarżonego (art. 72 \$ 2 k.p.k.). Za sprawą tej ustawy zrezygnowano również z obrony obligatoryjnej w przypadku oskarżonego, który nie włada w wystarczającym stopniu językiem polskim. Wspomnianą nowelizacją dodano także do art. 619 k.p.k. § 3, zgodnie z którym Skarb Państwa ponosi koszty związane z udziałem $\mathrm{w}$ postępowaniu tłumacza $\mathrm{w}$ zakresie koniecznym dla zapewnienia oskarżonemu jego prawa do obrony.

Nowela kodeksu z dnia 27 września 2013 r. ${ }^{11}$ stanowiła próbę adaptacji polskiego porządku prawnego do regulacji dyrektywy unijnej 2010/64/UE ${ }^{12}$. I tak: zmieniono art. $244 \$ 2$ k.p.k. dotyczący praw osoby zatrzymanej, jak też art. 72 § 2 k.p.k. odnoszący się do tłumaczenia kontaktów oskarżonego z obrońcą, poszerzono w art. 204 § 2 k.p.k. katalog podmiotów,

${ }^{8}$ Por. pierwotną wersję art. 72 k.p.k.: „Jeżeli oskarżony nie włada językiem polskim, postanowienie o przedstawieniu, uzupełnieniu lub zmianie zarzutów, akt oskarżenia oraz orzeczenie podlegające zaskarżeniu lub kończące postępowanie doręcza się oskarżonemu wraz z tłumaczeniem; za zgodą oskarżonego można poprzestać na ogłoszeniu przetłumaczonego orzeczenia kończącego postępowanie, jeżeli nie podlega ono zaskarżeniu”.

${ }^{9}$ Por. uchylony art. 407 k.p.k.

${ }_{10}$ Ustawa z dnia 10 stycznia 2003 r. o zmianie ustawy - Kodeks postępowania karnego, ustawy - Przepisy wprowadzające kodeks postępowania karnego, ustawy o świadku koronnym oraz ustawy o ochronie informacji niejawnych, Dz.U. 2003, nr 17, poz. 155; nr 111, poz. 1061.

${ }^{11}$ Ustawa z dnia 27 września 2013 r. o zmianie ustawy - Kodeks postępowania karnego oraz niektórych innych ustaw, Dz.U. 2013, poz. 1247.

12 Dyrektywa Parlamentu Europejskiego i Rady 2010/64/UE z dnia 20 października 2010 r. w sprawie prawa do tłumaczenia ustnego i tłumaczenia pisemnego w postępowaniu karnym, Dz.Urz.UE L 280/1 z dnia 26 października 2010 r. 
na rzecz których zachodzi potrzeba wezwania tłumacza w związku z potrzebą zapoznania ich $\mathrm{z}$ treścią przeprowadzanego dowodu, a także wprowadzono do wewnętrznego porządku prawnego art. 607 lit. 1 § 1a k.p.k., który gwarantuje prawo do tłumaczenia pisemnego osobie ściganej na podstawie europejskiego nakazu aresztowania.

Ostatni raz zmieniono oblicze normatywne prawa do tłumaczenia nowelizacją z dnia 28 listopada 2014 r. $^{13}$, na mocy której polski ustawodawca aspirował do zaadaptowania k.p.k. do wymogów wspomnianej dyrektywy Parlamentu Europejskiego i Rady 2012/29/UE. Wprowadzono wtedy do kodeksu - relewantne z punktu widzenia niniejszego opracowania - art. 56a oraz art. 60a dotyczące prawa do tłumaczenia pisemnego oskarżyciela posiłkowego oraz oskarżyciela prywatnego. Mimo deklaracji ${ }^{14}$ przywołana nowelizacja nie tylko nie sprostała wyzwaniu dostosowania prawa polskiego do wymagań dyrektywy unijnej 2012/29/UE, ale również nie spowodowała synchronizacji uprawnień oskarżonego i pokrzywdzonego w zakresie prawa do tłumaczenia.

\section{Analiza uregulowań Kodeksu postępowania karnego w przedmiocie prawa do tłumaczenia pokrzywdzonego}

Zgodnie z regulacjami art. 56a k.p.k. oraz art. 60a k.p.k. oskarżycielowi posiłkowemu oraz oskarżycielowi prywatnemu, którzy nie władaja w wystarczającym stopniu językiem polskim, orzeczenia podlegające zaskarżeniu lub kończące postępowanie doręcza się wraz z tłumaczeniem. Za ich zgodą można poprzestać na ogłoszeniu przetłumaczonego orzeczenia kończącego postępowanie, jeżeli nie podlega ono zaskarżeniu. Przywołane in extenso unormowania odnoszą się, po pierwsze, wyłącznie do prawa do tłumaczenia pisemnego, po drugie zaś, nie dotyczą sensu stricto pokrzywdzonego, lecz oskarżyciela posiłkowego oraz prywatnego, a zatem albo podmiotu, który jest pokrzywdzonym w przypadku przestępstw ściganych z oskarżenia prywatnego, albo pokrzywdzonego, który uzyskał status oskarżyciela posiłkowego na skutek wykazania odpowiedniej inicjatywy procesowej. Mowa tutaj o oświadczeniu pokrzywdzonego, że będzie działał w charakterze oskarżyciela posiłkowego, które kreuje go oskarżycielem posiłkowym bez potrzeby uzyskania orzeczenia o dopuszczeniu go do procesu ${ }^{15}$. Poczynione uwagi prowadzą do wniosku, zgodnie

${ }^{13}$ Ustawa z dnia 28 listopada 2014 r. o ochronie i pomocy dla pokrzywdzonego i świadka, Dz.U. 2015. poz. 21.

${ }_{14}$ Por. przyp. 1 do ustawy: http://isap.sejm.gov.pl/isap.nsf/download.xsp/WDU 20150000021/O/D20150021.pdf [dostęp: 15.04.2020].

15 Por. art. 53 i nast. k.p.k. 
z którym w odniesieniu do przestępstw ściganych z oskarżenia publicznego korzystanie z prawa do tłumaczenia pisemnego - rozumianego jako prawo do tłumaczenia określonych dokumentów procesowych pochodzących od organów procesowych - w przypadku pokrzywdzonego uzależnione jest od uzyskania statusu oskarżyciela posiłkowego. Ergo w toku postępowania sądowego i tzw. przejściowego prawo do tłumaczenia pisemnego nie przysługuje pokrzywdzonemu, który nie korzysta z uprawnień strony. Odnosząc się natomiast do fazy przedsądowej, należy stwierdzić, że pokrzywdzonemu nie przysługuje prawo do tłumaczenia pisemnego w toku postępowania przygotowawczego, bowiem - co oczywiste - na tym etapie postępowania karnego pokrzywdzony nie może uzyskać statusu oskarżyciela posiłkowego.

Skoro zatem - jak podniesiono - wprowadzone nowelą z 2014 r. art. 56a k.p.k. oraz art. 60a k.p.k. normują wyłącznie prawo do tłumaczenia pisemnego, to tym samym wypada stwierdzić, że zasadniczo pokrzywdzonemu w świetle Kodeksu postępowania karnego nie gwarantuje się prawa do tłumaczenia ustnego. Modyfikują to jednak w pewnym, niewielkim, stopniu przepisy art. $204 \S 1$ pkt 2 k.p.k. oraz art. $204 \S 2$ k.p.k. ${ }^{16}$. Należy bowiem przesądzić, że pierwszy z nich zapewnia prawo do tłumaczenia ustnego pokrzywdzonemu, ale wyłącznie w toku czynności procesowej przesłuchania, co więcej, li tylko w toku postępowania przygotowawczego. Analiza treści tego przepisu prowadzi do wniosku, zgodnie z którym jego hipoteza odnosi się także do pokrzywdzonego, ponieważ w rozumieniu tego przepisu pokrzywdzony jest „osobą niewładającą językiem polskim", ale - co trzeba podkreślić - tylko w zakresie zapewnienia pomocy tłumacza podczas przesłuchania, nie zaś $\mathrm{w}$ trakcie innych czynności procesowych $^{17}$. Doprecyzowując to stwierdzenie, należy wskazać, że chodzi o czynność przesłuchania pokrzywdzonego, nie zaś o przesłuchanie innego uczestnika procesu, w którym pokrzywdzony bierze udział. Mając zaś na względzie drugie z przywołanych uregulowań, należy stwierdzić, że zapewnia ono stronom prawo do zapoznania z treścią przeprowadzanego dowodu w języku dla nich zrozumiałym. Winno się przypomnieć, że treść omawianego przepisu uległa zmianie za sprawą przywoływanej już ustawy z dnia 27 września 2013 r. Wtedy też zwrot „oskarżonego” zastąpiono zwrotem „strony”, tym samym poszerzając katalog beneficjentów tego uregulowania i rozciaggając prawo do tłumaczenia $\mathrm{w}$ tym zakresie m.in. na pokrzywdzonego.

16 Więcej na ten temat por. K. WoźNIEwsKI: Prawidłowość czynności procesowych $w$ polskim procesie karnym. Gdańsk 2010, s. 149 i nast.

17 Podobnie S. STACHOWiaK: Uprawnienia pokrzywdzonego do korzystania z ttumacza $w$ polskim procesie karnym. Prok. i Pr. 2000, nr 12, s. 11-12. 
Gwarancyjna funkcja przepisu art. $204 \S 2$ k.p.k. w zakresie odnoszącym się do prawa do tłumaczenia ustnego realizuje się na płaszczyźnie uprawnień pokrzywdzonego w niewielkim stopniu. Przez „zapoznanie pokrzywdzonego z treścią przeprowadzanego dowodu" należy rozumieć wyłącznie tłumaczenie czynności, w których pokrzywdzony bierze udział bierny i w związku z tym jest zapoznawany z ich przebiegiem. Z zakresu normatywnego tego przepisu wyłączony jest natomiast czynny aspekt prawa do tłumaczenia ustnego pokrzywdzonego. W związku z powyższym dyspozycją tego przepisu nie są objęte przypadki aktywnego udziału pokrzywdzonego w toku czynności procesowych.

Z powyżej zaprezentowanych uwag wynika, że przepisy k.p.k. w niezwykle wąskim zakresie gwarantują pokrzywdzonemu prawo do tłumaczenia. Jak sygnalizowano, zarysowany stan normatywny łagodzi w pewnym zakresie unormowanie art. 5 § 2 ustawy Prawo o ustroju sądów powszechnych. Zgodnie $\mathrm{z}$ tym przepisem osoba niewładająca $\mathrm{w}$ wystarczającym stopniu językiem polskim ma prawo do występowania przed sądem w znanym przez nią języku i bezpłatnego korzystania z pomocy tłumacza. Zakresem regulacji przywołanego przepisu objęta jest nie tylko rozprawa główna, ale także przykładowo udział pokrzywdzonego $\mathrm{w}$ toku posiedzenia $\mathrm{w}$ przedmiocie warunkowego umorzenia postępowania karnego bądź w przedmiocie konsensualnego zakończenia postępowania karnego. Oznacza to, że pokrzywdzonemu - niezależnie od tego, czy korzysta z uprawnień strony, czy też nie - winno się zapewnić asystę tłumacza przy wszystkich czynnościach z jego udziałem (mowa tu zarówno o biernym, jak i o czynnym udziale pokrzywdzonego). Wobec powyższego należy uznać, że analizowany przepis wypełnia lukę normatywną w zakresie prawa do tłumaczenia pokrzywdzonego, niemniej - co niezwykle istotne - wyłącznie w toku postępowania jurysdykcyjnego ${ }^{18}$. Nie ma bowiem wątpliwości, że omawiane unormowanie ma charakter ustrojowy, reguluje ustrój sądów powszechnych, a tym samym dotyczy wyłącznie postępowania sądowego. Poza sporem pozostaje również to, że art. $5 \S 2$ analizowanej ustawy normuje wyłącznie prawo do tłumaczenia ustnego. Przez występowanie przed sądem rozumie się bowiem wyłącznie komunikację ustną oraz pisemną z sądem, a zatem przede wszystkim prawo do tłumaczenia ustnego $\mathrm{w}$ postaci korzystania $\mathrm{z}$ pomocy tłumacza $\mathrm{w}$ toku rozprawy lub posiedzeń sądu, ale także $\mathrm{w}$ czasie wszelkich procesowych kontaktów z sądem ${ }^{19}$. Poza hipotezą analizowanego przepisu pozostaje natomiast prawo do tłumaczenia pisemnego, a wobec tego prawo do tłu-

18 C. Nowak: Prawo do korzystania z pomocy..., s. 96. Por. również: R.A. STEFański: Udziat ttumacza..., s. 368.

19 Prawo o ustroju sąów powszechnych. Ustawa o Krajowej Radzie Sąownictwa. Komentarz. Red. J. GuDOwsKI. LEX/el 2009. 
maczenia określonych dokumentów procesowych pochodzących od organów procesowych.

Podsumowując tę część rozważań, należy wskazać, że przepisy k.p.k. nie gwarantują pokrzywdzonemu w toku postępowania przygotowawczego - z wyjątkiem czynności procesowej przesłuchania oraz zapoznania pokrzywdzonego z treścią przeprowadzanego dowodu - prawa do tłumaczenia ustnego. Oznacza to, że zakresem tego prawa ustawodawca nie objął pokrzywdzonego w przypadku udziału we wszystkich czynnościach procesowych $\mathrm{w}$ toku postępowania przygotowawczego, lecz jedynie tych, w toku których przeprowadzane są dowody. Co więcej, jak wskazywano, treść przepisu art. $204 \S 2$ k.p.k. prowadzi do wniosku, że przez zapoznanie z treścią przeprowadzanego dowodu należy rozumieć te sytuacje, w których pokrzywdzony bierze udział bierny i w związku z tym jest zapoznawany z przebiegiem czynności. Dyspozycją tego przepisu nie są zaś objęte przypadki aktywnego udziału pokrzywdzonego $\mathrm{w}$ toku takich czynności. W odniesieniu zaś do prawa do tłumaczenia pisemnego - jak przesądzono - ustawodawca za sprawą regulacji art. 56a k.p.k. uzależnia to prawo w toku postępowania sądowego i tzw. przejściowego od uzyskania przez pokrzywdzonego statusu oskarżyciela posiłkowego, natomiast nie gwarantuje takiego prawa $\mathrm{w}$ ogóle $\mathrm{w}$ toku postępowania przygotowawczego.

Z powyższego zatem winno się wyprowadzić wniosek, że ani przepisy k.p.k., ani też art. $5 \S 2$ ustawy Prawo o ustroju sądów powszechnych nie daja podstawy prawnej do przetłumaczenia istotnych z punktu widzenia interesów pokrzywdzonego dokumentów procesowych $\mathrm{w}$ toku postępowania przygotowawczego, takich chociażby jak decyzje kończące to postępowanie $\mathrm{w}$ postaci np. postanowienia o umorzeniu postępowania czy odmowie jego wszczęcia bądź też w postaci aktu oskarżenia. Brak jest również w k.p.k. jednoznacznej podstawy prawnej do żądania przez pokrzywdzonego udzielenia mu w języku dla niego zrozumiałym pouczeń o jego prawach i obowiązkach procesowych, w tym też o prawie do tłumaczenia. Ze względów gwarancyjnych podstawy takiej należy doszukiwać się w art. 300 § 2 k.p.k., wywodząc tym samym z tego przepisu obowiązek organów procesowych do zapewnienia pokrzywdzonemu pouczeń w języku dla niego zrozumiałym.

Kończąc rozważania w przedmiocie zakresu przedmiotowego prawa do tłumaczenia pokrzywdzonego, wypada zauważyć, że ani k.p.k., ani też ustawa Prawo o ustroju sądów powszechnych - inaczej niż w odniesieniu do prawa do tłumaczenia oskarżonego - nie rozciągają tego prawa na kontakty pokrzywdzonego $\mathrm{z}$ pełnomocnikiem, i to zarówno $\mathrm{w}$ fazie postępowania przygotowawczego, jak też $\mathrm{w}$ toku postępowania jurysdykcyjnego. 


\section{Prawo do tłumaczenia pokrzywdzonego w świetle prawa unijnego}

Analizując prawo do tłumaczenia pokrzywdzonego, nie sposób abstrahować od prawa unijnego ${ }^{20}$. Omawiane $\mathrm{w}$ tej pracy prawo uregulowane zostało bowiem również przez prawodawcę unijnego w dyrektywie Parlamentu Europejskiego i Rady 2012/29/UE z dnia 25 października 2012 r. $^{21}$. W przywołanym zakresie winno się zwrócić szczególną uwagę na art. 7 ust. 1 aktu unijnego, w którym unormowano prawo do tłumaczenia ustnego ofiary przestępstwa. Przepis ten wskazuje, że tłumaczenie ustne powinno być gwarantowane co najmniej podczas wszelkich rozmów z ofiarą oraz jej przesłuchań w toku postępowania karnego, zarówno przed organami postępowania przygotowawczego, jak i sądowego, a także w związku z jej czynnym udziałem w rozprawie sądowej i we wszelkich niezbędnych posiedzeniach.

O ile wykładnia pojęcia „przesłuchania” nie nastręcza większych kłopotów interpretacyjnych, to użyte sformułowanie „wszelkich rozmów z ofiarą" nie sposób już uznać za jednoznaczne. Skoro jednak prawodawca unijny używa pojęcia „rozmowy”, a więc pewnej aktywności między figurami procesu, to poza zakresem prawa do tłumaczenia pozostają sytuacje biernego udziału ofiary przestępstwa w określonej czynności procesowej. Biorąc pod uwagę ratio legis dyrektywy oraz jej aksjologię, wypada przesądzić, że pojęcie „wszelkich rozmów z ofiarą” obejmuje także prawa do tłumaczenia ustnego kontaktów z pełnomocnikiem ofiary przestępstwa. Należy również zauważyć, że art. 7 ust. 1 dyrektywy 2012/29/UE ogranicza prawo do tłumaczenia ustnego ofiary przestępstwa wyłącznie do jej czynnego udziału w rozprawie sądowej i wszelkich niezbędnych posiedzeniach. Oznacza to, że ofierze przestępstwa w świetle dyrektywy nie przysługuje prawo do tłumaczenia ustnego całego przebiegu rozprawy i posiedzeń, natomiast wyłącznie tych części rozpraw i posiedzeń, podczas których podejmuje ona określoną aktywność, np. zabiera głos. Z kolei prawo do tłumaczenia pisemnego ofiary przestępstwa przewiduje art. 7 ust. 3 omawianej dyrektywy. Wskazana regulacja prawna nie zakreśla prawa do tłumaczenia pisemnego w odniesieniu do konkretnego momentu procesowego i poszczególnych czynności,

${ }^{20} \mathrm{~W}$ przypadku prawa do tłumaczenia oskarżonego por. Dyrektywę Parlamentu Europejskiego i Rady 2010/64/UE z dnia 20 października 2010 r. w sprawie prawa do tłumaczenia ustnego i tłumaczenia pisemnego w postępowaniu karnym, Dz.Urz.UE L 280/1 z dnia 26 października $2010 \mathrm{r}$.

${ }^{21}$ Dyrektywa Parlamentu Europejskiego i Rady 2012/29/UE z dnia 25 października 2012 r. ustanawiająca normy minimalne w zakresie praw, wsparcia i ochrony ofiar przestępstw oraz zastępująca decyzję ramową Rady 2001/220/WSiSW, Dz.Urz.UE L 315/57 z dnia 14 listopada 2012 r. 
natomiast delimituje to prawo w sposób przedmiotowy, odnosząc je do decyzji końcowych zapadłych w toku procesu. Dyrektywa precyzuje, że chodzi w tym przypadku o orzeczenia zawierające ustalenie winy lub $\mathrm{w}$ inny sposób kończące postępowanie karne ${ }^{22}$. Trzeba $\mathrm{z}$ tego wyciągnąć wniosek, że tłumaczeniu w świetle dyrektywy będą podlegać wszystkie decyzje kończące postępowanie karne związane z przestępstwami popełnionymi na szkodę ofiary, niezależnie od etapu, na którym znajduje się postępowanie. Mowa tu zatem nie tylko o wyroku sądu, ale także o wszelkich decyzjach kończących postępowanie karne podejmowanych przez organy prokuratorskie i policyjne ${ }^{23}$. Dyrektywa uściśla bowiem, że decyzja kończąca postępowanie powinna obejmować sytuacje, w których prokurator postanawia o wycofaniu zarzutów bądź umorzeniu postępowania ${ }^{24}$, a zatem $\mathrm{w}$ zakres omawianego pojęcia winna wchodzić również przykładowo decyzja o cofnięciu przez prokuratora skargi publicznej. Dyrektywa daje nadto ofierze - na jej wniosek - prawo żądania przetłumaczenia także uzasadnienia wskazanych powyżej decyzji bądź też krótkiego streszczenia tego uzasadnienia, z tym zastrzeżeniem, że żądanie to jest wyłączone w sytuacji, gdy zgodnie z prawem krajowym uzasadnienia takiego się nie sporządza, np. - jak wskazuje dyrektywa w art. 7 ust. 3 in fine - gdy jest ono poufne.

Zestawiając uregulowania prawa krajowego w odniesieniu do prawa do tłumaczenia z przepisami dyrektywy 2012/29/UE, należy wskazać, że k.p.k. nie gwarantuje pokrzywdzonemu w ogóle pisemnej odsłony prawa do tłumaczenia $\mathrm{w}$ toku postępowania przygotowawczego, co pozostaje $\mathrm{w}$ sprzeczności $\mathrm{z}$ regulacjami prawa unijnego, które obliguje państwa członkowskie do zapewnienia tłumaczenia - również $\mathrm{w}$ toku postępowania przygotowawczego - decyzji kończących postępowanie karne.

Wreszcie w analizowanym kontekście wypada zwrócić uwagę na zagadnienie prawa do tłumaczenia ustnego kontaktów pokrzywdzonego z pełnomocnikiem. Godzi się przypomnieć, że ustalono, iż użyte w dyrektywie pojęcie „wszelkich rozmów z ofiarą” obejmuje także prawo do tłumaczenia ustnego kontaktów ofiary z jej pełnomocnikiem. Jednocześnie przesądzono, że k.p.k. nie gwarantuje prawa do tłumaczenia ustnego kontaktów pokrzywdzonego z jego pełnomocnikiem, podczas gdy takie

22 Por. pkt 30 preambuły do dyrektywy.

${ }^{23}$ Tak też Dyrektywa Parlamentu Europejskiego i Rady 2012/29/UE ustanawiająca normy minimalne $w$ zakresie praw, wsparcia $i$ ochrony ofiar przestępstw. Red. E. BIEŃKOwsKA, L. Mazowiecka. Warszawa 2014, s. 73. Podobnie C. Kulesza: Projekt Europejskiej Dyrektywy $z$ dnia 18 maja 2011 r. $w$ sprawie wsparcia i ochrony ofiar $w$ świetle prawa polskiego. Prok. i Pr. 2011, nr 12, s. 28.

${ }^{24}$ Zob. pkt 44 preambuły do dyrektywy. 
prawo $\mathrm{w}$ odniesieniu do kontaktów z obrońcą ustawodawca krajowy $\mathrm{w}$ art. $72 \S 2$ k.p.k. przyznał oskarżonemu i podejrzanemu.

\section{Uwagi podsumowujące Postulaty de lege ferenda}

Zasada równości broni stron jest cechą sporu procesowego, będąc jednocześnie istotą kontradyktoryjności ${ }^{25}$. Jej istota sprowadza się do tego, by strony procesu miały równe prawa oraz by żadna z nich nie była w sytuacji gorszej niż druga ${ }^{26}$. Wskazywana zasada odnosi się do prawnej, nie zaś faktycznej równości. Należy jednocześnie zastrzec, że zasada równości broni nie oznacza idealnej symetrii uprawnień procesowych, a takie ukształtowanie przepisów procesu karnego, które w takim samym stopniu będzie pozwalać stronom na realizację ich praw w tym procesie. Analiza przepisów k.p.k. i ustawy Prawo o ustroju sądów powszechnych w zakresie odnoszącym się do prawa do tłumaczenia pozwoliła na pozytywną weryfikację tezy o braku równości uprawnień oskarżonego i pokrzywdzonego.

Nie ma wątpliwości, że nie do zaakceptowania w świetle wymogów równości broni oraz wyrażonej w art. $2 \S 1$ pkt 3 k.p.k. potrzeby uwzględnienia prawnie chronionych interesów pokrzywdzonego przy jednoczesnym poszanowaniu jego godności jest asymetria uprawnień w zakresie prawa do tłumaczenia oskarżonego i pokrzywdzonego ${ }^{27}$. Podejmowana analiza prawa do tłumaczenia $\mathrm{w}$ świetle zasady równości broni - co należy podkreślić - odnosi się wyłącznie do tych sytuacji procesowych, $\mathrm{w}$ których pokrzywdzony w toku procesu karnego występuje w roli strony. Mowa tu zatem o etapie postępowania przygotowawczego oraz postępowania jurysdykcyjnego, ale tylko w zakresie, w którym pokrzywdzony działa w charakterze oskarżyciela posiłkowego bądź prywatnego.

Jak wykazano, mimo że art. 5 § 2 ustawy Prawo o ustroju sądów powszechnych $\mathrm{w}$ wielu fragmentach uzupełnia regulacje k.p.k., to jednak bez trudu można zidentyfikować takie obszary normatywne, w których

25 В. ВіEŃкоWsKa: Zasady procesu karnego. W: Wyktad prawa karnego procesowego. Red. P. KRUSZYŃsKI. Białystok 2012.

${ }^{26}$ Por. przykładowo wyr. ETPC z dnia 27 października 1993 r. w sprawie Dombo Beheer p. Niderlandom (skarga nr 14448/88). Więcej na ten temat zob. M. WĄSEK-WIADEREK: Zasada równości stron $w$ polskim procesie karnym $w$ perspektywie prawnoporównawczej. Kraków 2003.

${ }^{27} \mathrm{Na}$ asymetrię uprawnień pokrzywdzonego i oskarżonego w zakresie prawa do tłumaczenia wskazuje m.in. H. PALuszKiewicz: Nowe środki ochrony pokrzywdzonego $w$ polskim prawie karnym procesowym na tle europejskiej polityki karnej. RPEiS 2010, nr 3, s. 8. 
ani przepisy Kodeksu postępowania karnego, ani unormowania ustawy Prawo o ustroju sądów powszechnych - w przeciwieństwie do uprawnień oskarżonego - nie gwarantują pokrzywdzonemu prawa do tłumaczenia. Przykładem może być niezwykle istotne z punktu widzenia interesów ofiary przestępstwa prawo do tłumaczenia pisemnego $\mathrm{w}$ toku postępowania przygotowawczego. Trudno zatem uznać, że jeden z celów stawianych przez k.p.k., jakim jest ochrona interesów pokrzywdzonego, realizowany jest na płaszczyźnie prawa do tłumaczenia w sytuacji, gdy - jak przesądzono - pokrzywdzonemu nie przysługuje pełnia prawa do tłumaczenia $\mathrm{w}$ toku postępowania przygotowawczego.

Równie istotna w omawianym zakresie - jak wskazywano powyżej jest perspektywa realizacji założeń zasady kontradyktoryjności, co szczególnie widać $\mathrm{w}$ fazie postępowania przygotowawczego. Należy zważyć na to, że etap prowadzenia postępowania przygotowawczego ma zasadnicze znaczenie dla przygotowania postępowania karnego, jako że materiał dowodowy uzyskiwany na tym etapie postępowania determinuje ramy, $\mathrm{w}$ jakich oskarżenie o czyn zagrożony kara zostanie rozpatrzone na rozprawie $^{28}$. Zasadą tego postępowania jest inkwizycyjność, co powoduje, że przejawy kontradyktoryjności są ściśle reglamentowane przez przepisy k.p.k., a częściowo także zależne od organów prowadzących dochodzenie bądź śledztwo. Toteż należy uznać, że brak możliwości korzystania przez pokrzywdzonego z pomocy tłumacza w sposób znaczny utrudnia jego udział w postępowaniu przygotowawczym ${ }^{29}$, co w sposób oczywisty uniemożliwia mu zapoznanie się z materiałem dowodowym, wypowiedzenie się odnośnie do przeprowadzonych dowodów czy wreszcie składanie wniosków dowodowych. W analizowanym kontekście wypada zatem zgodzić się ze Stanisławem Stachowiakiem ${ }^{30}$, który słusznie wskazuje, że $\mathrm{w}$ tym przypadku wątpliwe jest zachowanie reguły równego traktowania stron procesu ${ }^{31}$.

Wybiórcza regulacja prawa do tłumaczenia pokrzywdzonego na płaszczyźnie k.p.k. może budzić zdziwienie z perspektywy ostatnich noweli kodeksu odnoszących się do uprawnień pokrzywdzonego. Obserwuje się $\mathrm{w}$ omawianym zakresie niekonsekwencję ustawodawcy, który przecież na gruncie kolejnych zmian kodeksowych poszerzał istotnie uprawnie-

${ }^{28}$ Tak też słusznie Kodeks postępowania karnego. Komentarz do art. 1-166. Red. R.A. STEFaŃSKI, S. ZAвŁocKi. Warszawa 2017, s. 825.

${ }^{29}$ K. Witкowska: Tłumacz w postępowaniu karnym. Prok. i Pr. 2014, nr 1, s. 40.

30 S. STACHOWiak: Uprawnienia..., s. 14.

${ }^{31}$ Na nierówność stron $\mathrm{w}$ analizowanym zakresie zwracała też uwagę w piśmiennictwie M. WĄSEK-WIADEREK: Zasada równości stron..., s. 223-224. 
nia pokrzywdzonego ${ }^{32}$, czego nie uczynił jednak w odniesieniu do prawa do tłumaczenia. W związku z tym należy postulować nowelizację przepisów k.p.k. w kierunku uzupełniania luk normatywnych odnoszących się do prawa do tłumaczenia pokrzywdzonego w zakresie, o którym była już mowa, w celu wyrównania uprawnień procesowych pokrzywdzonego i oskarżonego ${ }^{33}$. O ile bowiem można zaakceptować uzależnienie skorzystania $\mathrm{z}$ prawa do tłumaczenia pisemnego $\mathrm{w}$ toku postępowania sądowego i tzw. przejściowego od uzyskania przez pokrzywdzonego statusu oskarżyciela posiłkowego, o tyle nie sposób uznać za zasadny stan normatywny, w którym przepisy k.p.k. i ustawy Prawo o ustroju sądów powszechnych nie gwarantują w ogóle pokrzywdzonemu tego prawa w toku postępowania przygotowawczego. Podobnie jak brak uzasadnienia dla tak wąskiego zakresu prawa do tłumaczenia ustnego pokrzywdzonego w toku postępowania przygotowawczego.

Po drugie, przeprowadzona egzegeza uregulowań k.p.k. i ustawy Prawo o ustroju sądów powszechnych dowiodła słuszności tezy, że prawo do tłumaczenia w polskim procesie karnym w zakresie odnoszącym się do pokrzywdzonego nie jest całościowo regulowane przez unormowania k.p.k., a niektóre jego fragmenty normatywne trzeba dekodować z ustawy Prawo o ustroju sądów powszechnych. O ile w pełni zrozumiałe jest, że ustawodawca w sposób ogólny reguluje pewne kwestie związane z przebiegiem postępowania sądowego, $\mathrm{w}$ tym prawo do tłumaczenia, poza ustawami procesowymi, o tyle jako wadliwy należy ocenić brak konkretyzacji prawa do tłumaczenia w regulacjach kodeksowych. Nie można w ramach omawianego zakresu zapominać, że przepis art. 5 § 2 ustawy Prawo o ustroju sądów powszechnych ma charakter niezwykle ogólny, nie precyzuje on bowiem chociażby zakresu przedmiotowego prawa do tłumaczenia. Wobec tego winno się postulować całościowe i precyzyjne uregulowanie prawa do tłumaczenia w k.p.k., bowiem obie sfery normatywne, o których tu mowa, wzajemnie się przenikają, zaś niejasna relacja między nimi powoduje trudności w praktycznym stosowaniu przepisów, a w konsekwencji

32 Por. choćby legislacyjne zmiany odnoszące się do możliwości sprzeciwu pokrzywdzonego w przypadku wniosków składanych w trybie art. 335 k.p.k.

${ }^{33}$ Konieczność nowelizacji, o której tu mowa, postulowali nie tylko przedstawiciele nauki prawa, ale także politycy. Senator R. Knosala w oświadczeniu skierowanym do Ministra Sprawiedliwości Krzysztofa Kwiatkowskiego zwrócił uwagę na braki legislacyjne odnoszące się do prawa do tłumaczenia osoby pokrzywdzonej. Por. oświadczenie senatora Ryszarda Knosali skierowane do Ministra Sprawiedliwości Krzysztofa Kwiatkowskiego na 64. posiedzeniu Senatu w dniu 4 listopada 2010 r. (dostępne na stronie internetowej Senatu RP - www.senat.gov.pl); za: M. OlesIUK: Wptyw regulacji Unii Europejskiej na prawo pokrzywdzonego do pomocy ttumacza $w$ polskiej procedurze karnej. „Białostockie Studia prawnicze” 2014, nr 15, s. 205. 
w dekodowaniu prawa do tłumaczenia. Jest to bezspornie sytuacja niepożądana z punktu widzenia standardu pewności i transparentności prawa.

Wreszcie godzi się również przesądzić, że normatywnego kształtu prawa do tłumaczenia pokrzywdzonego na płaszczyźnie k.p.k. i ustawy Prawo o ustroju sądów powszechnych nie da się pogodzić z wymogami unijnej dyrektywy Parlamentu Europejskiego i Rady 2012/29/UE. Innymi słowy, prawo krajowe w odniesieniu do prawa do tłumaczenia pokrzywdzonego nie spełnia wszystkich wymogów stawianych przez unijny porządek prawny, co może mieć znaczące konsekwencje wynikające ze specyfiki współistnienia prawa krajowego oraz unijnego porządku prawnego, skutkujące nie tylko „przekazaniem pola” unijnemu porządkowi prawnemu kosztem prawa krajowego, ale także groźbą zastosowania wobec Rzeczypospolitej Polskiej przewidzianych w Traktacie o Funkcjonowaniu Unii Europejskiej ${ }^{34}$ sankcji ${ }^{35}$.

\section{Bibliografia}

\section{Literatura}

BIEŃкоWsKA B.: Zasady procesu karnego. Białystok 2012.

Dyrektywa Parlamentu Europejskiego i Rady 2012/29/UE ustanawiajaca normy minimalne $w$ zakresie praw, wsparcia $i$ ochrony ofiar przestępstw. Red. E. BIEŃKOWsKA, L. MazowIECKA. Warszawa 2014.

Kodeks postępowania karnego. Komentarz. Red. A. SAKowicz. Warszawa 2018.

Kodeks postępowania karnego. Komentarz. Red. K. DudKA. Warszawa 2018.

Kodeks postępowania karnego. Komentarz do art. 1-166. Red. R.A. STEFańsKI, S. ZABŁOCKI. Warszawa 2017.

Kulesza C.: Projekt Europejskiej Dyrektywy z dnia 18 maja 2011 r. w sprawie wsparcia i ochrony ofiar w świetle prawa polskiego. Prok. i Pr. 2011, nr 12.

Marszat K.: Proces karny. Zagadnienia ogólne. Katowice 2009.

NowaK C.: Prawo do korzystania $z$ pomocy tłumacza $w$ europejskim i polskim prawie karnym. Prok. i Pr. 1998, nr 10.

OlesIUK M.: Wptyw regulacji Unii Europejskiej na prawo pokrzywdzonego do pomocy tłumacza $w$ polskiej procedurze karnej. „Białostockie Studia Prawnicze” 2014, nr 15.

PaluszKIEWICZ H.: Nowe środki ochrony pokrzywdzonego w polskim prawie karnym procesowym na tle europejskiej polityki karnej. RPEiS 2010, nr 3.

PєAChTA M.: Postępowanie karne przeciwko cudzoziemcowi w świetle badań empirycznych. SP 1990, nr 2.

34 Traktat o Funkcjonowaniu Unii Europejskiej, Dz.Urz.UE C 326/47 z dnia 26 października $2012 \mathrm{r}$.

35 Por. przede wszystkim art. 258-260 TFUE. 
Ponikowski R., Posnow W., Skorupka J., Świda Z. W: Postępowanie karne. Część ogólna. Red. J. SKorUPKA. Warszawa 2008.

Prawo o ustroju sądów powszechnych. Ustawa o Krajowej Radzie Sądownictwa. Komentarz. Red. J. GudowsKI. LEX/el 2009.

Schabas W.A.: The European Convention on Human Rights. A commentary. Oxford 2015.

SowIŃSKI P.K.: Uprawnienia składajace się na prawo oskarżonego do obrony. Uwagi na tle czynności oskarżonego oraz organów procesowych. Rzeszów 2012.

STACHOWIAK S.: Uprawnienia pokrzywdzonego do korzystania $z$ ttumacza $w$ polskim procesie karnym. Prok. i Pr. 2000, nr 12.

StEFAŃsKi R.A.: Tłumacz $w$ procesie karnym. „Wojskowy Przegląd Prawniczy” 2006, nr 4.

STEFAŃSKI R.A.: Udział tłumacza $w$ postępowaniu karnym jako przejaw rzetelnego procesu karnego. W: Rzetelny proces karny. Ksiega Jubileuszowa Profesor Zofii Świdy. Red. J. SKorupKa. Warszawa 2009.

Świda Z.: Prawo cudzoziemca do obrony. W: Przestępczość przygraniczna. Postępowanie karne przeciwko cudzoziemcom $w$ Polsce. Red. A.J. Szwarc. Poznań 2000.

WĄSEK-WIADEREK M.: Zasada równości stron $w$ polskim procesie karnym $w$ perspektywie prawnoporównawczej. Kraków 2003.

WiLIŃsKi P.: Zasada prawa do obrony $w$ polskim procesie karnym. Warszawa 2006.

Witkowska K.: Ttumacz w postępowaniu karnym. Prok. i Pr. 2014, nr 1.

WoźnIEWsKi K.: Prawidłowość czynności procesowych $w$ polskim procesie karnym. Gdańsk 2010.

\section{Akty prawne}

Ustawa z dnia 6 czerwca 1997 r. Kodeks postępowania karnego, t.j. Dz.U. 2020, poz. 30, 413, 568, 1086.

Ustawa z dnia 27 lipca 2001 r. - Prawo o ustroju sądów powszechnych, t.j. Dz.U. 2020, poz. 365, 288, 875, 1086.

Ustawa z dnia 10 stycznia 2003 r. o zmianie ustawy - Kodeks postępowania karnego, ustawy - Przepisy wprowadzające kodeks postępowania karnego, ustawy o świadku koronnym oraz ustawy o ochronie informacji niejawnych, Dz.U. 2003, nr 17, poz. 155; nr 111, poz. 1061.

Ustawa z dnia 27 września 2013 r. o zmianie ustawy - Kodeks postępowania karnego oraz niektórych innych ustaw, Dz.U. 2013, poz. 1247.

Ustawa z dnia 28 listopada 2014 r. o ochronie i pomocy dla pokrzywdzonego i świadka, Dz.U. 2015, poz. 21.

Traktat o Funkcjonowaniu Unii Europejskiej, Dz.Urz.UE C 326/47 z dnia 26 października 2012 r.

Dyrektywa Parlamentu Europejskiego i Rady 2010/64/UE z dnia 20 października 2010 r. w sprawie prawa do tłumaczenia ustnego i tłumaczenia pisemnego w postępowaniu karnym, Dz.Urz.UE L 280/1 z dnia 26 października $2010 \mathrm{r}$. 
Dyrektywa Parlamentu Europejskiego i Rady 2012/29/UE z dnia 25 października 2012 r. ustanawiająca normy minimalne w zakresie praw, wsparcia i ochrony ofiar przestępstw oraz zastępująca decyzję ramową Rady 2001/220/WSiSW, Dz.Urz.UE L 315/57 z dnia 14 listopada 2012 r.

\section{Orzecznictwo}

Wyr. SN z dnia 3 kwietnia 2003 r., III KKN 143/01. LEX nr 78914.

Wyr. SN z dnia 22 marca 2007 r., V KK 190/06. Prok. i Pr. 2007, nr 10, poz. 11. Wyr. ETPC z dnia 27 października 1993 r. w sprawie Dombo Beheer p. Niderlandom (skarga nr 14448/88). 